\title{
Essential Role of Myosin Light Chain Kinase in the Mechanism for MgATP-Dependent Priming of Exocytosis in Adrenal Chromaffin Cells
}

\author{
Konosuke Kumakura, ${ }^{1}$ Kimihito Sasaki, ${ }^{1}$ Takashi Sakurai, ${ }^{2}$ Mica Ohara-Imaizumi, ${ }^{1}$ Hiroaki Misonou, ${ }^{1}$ Seiji \\ Nakamura, ${ }^{2}$ Yuzuru Matsuda, ${ }^{3}$ and Yoshiaki Nonomura ${ }^{2}$ \\ ${ }^{1}$ Life Science Institute, Sophia University, Tokyo 102, ${ }^{2}$ Department of Pharmacology, Faculty of Medicine, University of \\ Tokyo, Tokyo 113, and ${ }^{3}$ The Tokyo Research Laboratories, Kyowa Hakko Kogyo Co., Ltd., Tokyo 194, Japan
}

\begin{abstract}
$\mathrm{Ca}^{2+}$-induced exocytosis in chromaffin cells now seems to consist of at least two distinct steps: MgATP-dependent $\mathrm{Ca}^{2+}$. enhanced priming of the secretory apparatus, and $\mathrm{Ca}^{2+}$-dependent MgATP-independent step that triggers exocytosis (Bittner and Holz, 1992). Recently we found that a specific inhibitor of myosin light chain kinase (MLCK), wortmannin, inhibits $\mathrm{Ca}^{2+}$-induced catecholamine release from digitoninpermeabilized chromatfin cells, suggesting an implication of MLCK in the mechanisms of $\mathrm{Ca}^{2+}$-induced exocytosis (Imaizumi et al., 1992b). To elucidate further the implication of MLCK in the mechanism of exocytosis, we studied the effects of wortmannin and a peptide inhibitor (SM-1) corresponding to the pseudosubstrate domain of MLCK on MgATPdependent and MgATP-independent release in digitoninpermeabilized chromaffin cells. $\mathrm{Ca}^{2+}$-induced exocytosis from the permeabilized cells in the presence of MgATP was inhibited by both SM-1 and wortmannin. Inhibitory effect of wortmannin on the rate of release induced by $10 \mu \mathrm{M} \mathrm{Ca}{ }^{2+}$ in the presence of MgATP was much prominent in the later phase (1-10 $\mathrm{min})$, although the initial rate was also decreased. SM-1 strongly inhibited ATP-dependent release without affecting $\mathrm{Ca}^{2+}$-dependent ATP-independent release at all. In addition, priming effect of MgATP that underlies $\mathrm{Ca}^{2+}$-dependent ATP-independent release was remarkably reduced by both wortmannin and SM-1. These results suggest that MLCK plays an essential role in ATP-dependent priming of $\mathrm{Ca}^{2+}$-induced exocytosis in chromaffin cells.
\end{abstract}

IKey words: chromaffin cells, exocytosis, myosin light chain kinase, ATP-dependent priming, wortmannin, MLCK pseudosubstrate domain peptide]

Recent studies on mechanisms of regulated secretion in chromaffin cells have revealed possible implication of guanine nucleotides and guanine nucleotide-binding proteins (Knight and Baker, 1985; Bittner et al., 1986; Ohara-Imaizumi et al., 1992a; Vitale et al., 1993), various protein kinases (Morgan and Bur-

\footnotetext{
Received Sept. 28, 1993; revised June 6, 1994; accepted June 9, 1994

We thank Dr. T. Kanno and Ms. R. Nagata for help with Argus-100/Ca. This work was supported in part by Grants-in-Aid for Scientific Research from the Ministry of Education, Science and Culture of Japan to K.K. and to M.O.-I. The Sasakawa Scientific Research Grant from The Japan Science Society to M.O.-I. is also acknowledged.

Correspondence should be addressed to Konosuke Kumakura, Ph.D., Life Science Institute, Sophia University, 7-1, Kioi-cho, Chiyoda-ku, Tokyo 102, Japan. Copyright (C) 1994 Society for Neuroscience $0270-6474 / 94 / 147695-09 \$ 05.00 / 0$
}

goyne, 1990; Terbush and Holz, 1990; Wilson, 1990; OharaImaizumi et al., 1992b), cytoplasmic proteins (Sarafian et al., 1987; Ali et al., 1989; Morgan and Burgoyne, 1992; Nishizaki et al., 1992), and granule-associated proteins (Darchen et al., 1990; Perin et al., 1991; Elferink et al., 1993). While the progress by these studies does not allow us yet to fully understand the biochemical events responsible for regulated exocytosis, multiple processes in $\mathrm{Ca}^{2+}$-dependent secretion have been suggested recently. Holz and collaborators suggested that MgATP primed secretion before $\mathrm{Ca}^{2+}$-triggering process in digitonin-permeabilized cells, and that $\mathrm{Ca}^{2+}$-evoked exocytosis from the primed pool was independent of ATP (Holz et al., 1989; Bittner and Holz, 1992). Hay and Martin (1992) dissected the regulated secretion, in mechanically disrupted PC12 cells, into MgATPdependent priming and $\mathrm{Ca}^{2+}$-dependent MgATP-independent triggering stages. In mast cells permeabilized by streptolysin-O, ATP was required to maintain a high affinity of the response system for $\mathrm{Ca}^{2+}$ and GTP $\gamma$ S, but was not required for the final stage of triggered exocytosis (Howell et al., 1989).

Recently we reported the inhibition by wortmannin of $\mathrm{Ca}^{2+}$ induced catecholamine (CA) release from digitonin-permeabilized chromaffin cells as well as the release by $\mathrm{ACh}$ and high $\mathrm{K}^{+}$ from the intact cells (Ohara-Imaizumi et al., 1992b). Wortmannin inhibits myosin light chain kinase (MLCK) specifically and potently (Nakanishi et al., 1992). Thus, we suggested an implication of MLCK in the mechanisms of $\mathrm{Ca}^{2+}$-induced exocytosis. Possible involvement of the contractile proteins or their regulatory proteins in the mechanism of exocytosis in chromaffin cells has been proposed from earlier (Douglas and Rubin, 1964; Poisner and Trifaro, 1967; Trifaro, 1978). MLCK is present in adrenal medulla (Kanda et al., 1985), and exogenous MLCK or secretagogues have been shown to phosphorylate intracellular myosin light chain (MLC) in these cells (Lee et al., 1987; Gutierrez et al., 1989). Despite these findings, physiological studies have failed to provide any evidence that suggests the involvement of MLCK activation in the mechanism of exocylosis (Lee et al., 1987; Nakanishi et al., 1989) until our previous report (Ohara-Imaizumi, 1992b).

To clarify the implication of MLCK activation in the multiple processes for the regulated exocytosis, in this study we examined the effects of inhibition of MLCK activation on MgATP-dependent and MgATP-independent release of CA in digitoninpermeabilized chromaffin cells. We particularly used a potent inhibiting peptide, SM-1, that corresponds to the pseudosubstrate domain of MLCK required for autoinhibition (Kargacin 
et al., 1990) and other inhibiting peptides in addition to wortmannin. We also studied the localization of myosin II for understanding the site of MLCK implication.

\section{Materials and Methods}

Primary cultures. Adrenal chromaffin cells were isolated from fresh bovinc adrcnal glands by collagenase digestion, and cells were purified by differential plating as previously described (Kumakura et al., 1986). The purified chromaffin cells were plated $\left(3 \times 10^{5}\right.$ cells $\left./ \mathrm{ml}\right)$ on collagencoated $16 \mathrm{~mm}$ diameter dishes (Nunc), and were maintained in monolayer culture in Dulbecco's modified Eagle's Medium (DMEM; GIBCO) supplemented with $10 \%$ fetal calf serum (Boehringer Mannheim) as was described previously (Ohara-Imaizumi et al., 1992a). All the experiments were performed with the cells in culture for 3-10 d.

Permeabilization of cells. The chromaffin cells in monolayer were permeabilized by incubating for $4 \mathrm{~min}$ at $37^{\circ} \mathrm{C}$ in a buffer (P-buffer) containing $140 \mathrm{~mm}$ Na-glutamate, $20 \mathrm{~mm}$ PIPES, $5 \mathrm{~mm}$ glucose, $5 \mathrm{~mm}$ EGTA, and $0.02 \mathrm{~mm}$ digitonin (Calbiochem) adjusted $\mathrm{pH}$ to 6.80 with $\mathrm{NaOH}$ (Ohara-Imaizumi, 1992a). This permeabilizing buffer was subsequently replaced with a buffer for a secretion experiment.

Secretion experiments. The release of CA from the digitonin-permeabilized cells was measured as previously described (Ohara-Imaizumi, et al., 1992a). At the end of permeabilization, P-buffer was replaced with a buffer (S-buffer) containing (in mM) 140 Na-glutamate, 20 piperazine- $N, N^{\prime}$-bis(2-ethanesulfonic acid) (PIPES), 5 glucose, 5 $\mathrm{MgSO}_{4}, 5 \mathrm{ATP}$, and 5 EGTA (without or with various amount of $\mathrm{CaCl}_{2}$ ), with $\mathrm{pH}$ adjusted to 6.80 with $\mathrm{NaOH}$. The cells were incubated for an additional $6 \mathrm{~min}$ and the medium was collected for measurement of $\mathrm{Ca}^{2+}$-evoked CA release. Calcium concentrations in $\mathrm{Ca}^{2+}-$ EGTA buffers were calculated according to Nanninga and Kempen (1971). For the measurement of MgATP-independent release, the cells were incubated for 1-2 min in S-buffer containing $100 \mu \mathrm{M} \mathrm{Ca}{ }^{2+}$ without $\mathrm{MgSO}_{4}$ and ATP. For MgATP-dependent release, the concentration of free $\mathrm{Ca}^{2+}$ in S-buffer was adjusted to $10 \mu \mathrm{M}$, and the cells were incubated for $6 \mathrm{~min}$ according to Bittncr and $\mathrm{Holz}(1992)$ in the presence of $5 \mathrm{~mm} \mathrm{MgSO}_{4}$ and $5 \mathrm{~mm}$ ATP. The release of endogenous CA from intact chromaffin cells in monolayer culture was measured as previously described (OharaImaizumi et al., 1992a). Briefly, the cells were stimulated in Locke's solution for $3 \mathrm{~min}$ following the preincubation for $30 \mathrm{~min}$ at $30^{\circ} \mathrm{C}$. Released CA and cellular CA were extracted with $0.4 \mathrm{~m}$ perchloric acid and assayed by HPLC (Kumakura et al., 1986).

Priming effect of $A T P$. To examine the priming effect of ATP, priming incubation was done simultaneously with permeabilization for $4 \mathrm{~min}$ in the permeabilizing buffer (P-buffer) containing $5 \mathrm{mM} \mathrm{MgSO}_{4}$, with or without $5 \mathrm{~mm}$ ATP. The buffer was subsequently replaced with S-buffer without ATP, and $\mathrm{MgATP}$-independent release was measured.

Wortmannin and MLCK-inhibiting peptides. Wortmannin was prepared as previously described (Nakanishi et al., 1992). SM-1 was synthesized and purified according to Wysolmcrski and Lagunoff (1991). SM-1 has the following sequence: Ala-Lys-Lys-Leu-Ser-Lys-Asp-ArgMet-Lys-Lys-Tyr-Met-Ala-Arg-Arg- Lys-Trp-Gln-Lys-Thr-Gly (MLCK, 480-501). Myosin kinase-inhibiting peptide (MKIP; Lys-Lys-Arg-AlaAla-Arg-Ala-Thr-Ser- $\mathrm{NH}_{2}$; analog of $\left.\mathrm{MLC}_{20}, 11-19\right)$ and $\mathrm{N}$-terminal acetylated MKIP (MKIPAc) were prepared according to Hunt et al. (1989). A pseudosubstrate peptide for MLCK (K-MLC 11-23), and for protein kinase $\mathrm{C}$ (PKC), [Ser25]PKC(19-31), were purchased from Peninsula Laboratories (Belmont, CA).

To examine the effects of wortmannin, $30 \mathrm{~min}$ preincubation was done in the presence of the drug prior to the digitonin permeabilization. The peptide inhibitors were added in the pemeabilizing P-buffer and also in S-buffer for some experiments (see figure captions).

Monitoring of intracellular calcium. For the monitoring of intracellular calcium, the cells cultured on a coverslips coated with Cell-Tak (Biopolymers, Farmington, CT) were loaded with $2 \mu \mathrm{M}$ fura-2/AM in DMEM for $1 \mathrm{hr}$ at $37^{\circ} \mathrm{C}$ using a Sykus-Moore culture chamber, and rinsed three times with Locke's solution. Fura-2-loaded cells were incubated for another $30 \mathrm{~min}$ in the presence or absence of wortmannin prior to $\mathrm{Ca}^{2+}$ monitoring. The cells were superfused $(2 \mathrm{ml} / \mathrm{min})$ with Locke's solution at $30^{\circ} \mathrm{C}$ for fluorescence measurement. Digital imaging of fura-2 fluorescence was carried out with an inverted microscope (TMD-2, Nikon, Tokyo, Japan) and a digital image processor (Argus100/Ca, Hamamatsu Photonics, Hamamatsu, Japan). The concentration of intracellular free $\mathrm{Ca}^{2+}\left(\left[\mathrm{Ca}^{2+}\right]_{i}\right)$ was estimated from the fluo- rescence ratio ( $340 \mathrm{~nm}: 380 \mathrm{~nm}$ ) using the equation described by Grynkiewicz et al. (1985).

Preparation of antibody and immunoblotting. Myosin heavy chain was purified from chicken gizzard smooth muscle according to the method previously described (Nakamura and Nonomura, 1984). Preparation and characteristics of polyclonal anti-myosin II IgG will be described in details elsewhere (Ogiwara, unpublished observations). This antibody specifically and strongly reacted with mammalian nonmuscle myosin II heavy chain as well as smooth muscle one (see Results and Fig. 10A).

For immunoblotting, cultured chromaffin cells were collected after rinsed with PBS, and homogenized by a small Grass-homogenizer in the solution containing $50 \mathrm{~mm} \mathrm{KCl}, 25 \mathrm{~mm}$ Tris- $\mathrm{HCl}(\mathrm{pH} 7.6), 50 \mu \mathrm{M}$ DFP, $50 \mu \mathrm{M} \mathrm{NaN}$, and $1 \mathrm{mM} \mathrm{MgCl}$. The homogenate was centrifuged in an Eppendorf tube at $3500 \times g$ for $10 \mathrm{~min}$. The supernatant was centrifuged at $16,000 \times g$ for $90 \mathrm{~min}$, and the precipitate solved in SDS solution was used as microsome-rich fraction. Proteins resolved by SDSPAGE were transferred to nitrocellulose sheets (Schleicher and Schuell, Inc.; $0.25 \mu \mathrm{m}$ ), and after staining with Ponceau $S$ and photographed, the samples were reacted with anti myosin II IgG (diluted 1:500) and HRP-conjugated anti-rabbit IgG according to the conventional method, and stained with 4-chloro-naphthyl phosphate.

Immunofluorescent microscopy. Chromaffin cells cultured on coverslips were fixed with $0.8 \%$ paraformaldehyde in PBS for 1 min and, after washing with PBS, with $100 \%$ acetone for $5 \mathrm{~min}$ at room temperature. The cells were treated with $1 \%$ Triton X-100 in PBS for 5 min at room temperature, rinsed in PBS, and then incubated with the blocking solution containing $2.5 \%$ bovine serum albumin and $2 \%$ chicken serum for $30 \mathrm{~min}$. Subsequently, the cells were incubated with anti myosin II IgG (diluted $1: 400$ ) for $3 \mathrm{hr}$ at $37^{\circ} \mathrm{C}$. $\Lambda \mathrm{fter}$ rinsing in $400 \mathrm{~mm}$ $\mathrm{MgCl}_{2}$ and $20 \mathrm{~mm}$ Tris- $\mathrm{HCl}(\mathrm{pH} \mathrm{7.6})$ and PBS, the cells were incubated for $1 \mathrm{hr}$ at $37^{\circ} \mathrm{C}$ with FITC-conjugated anti rabbit IgG in the blocking solution. The samples were mounted in 5\% DABCO in PBS/glycerol (1:1) and visualized under Nikon FEX-A fluorescent microscopy.

\section{Results}

\section{Inhibition of $C A$ release by wortmannin}

Preincubation of adrenal chromaffin cells with wortmannin produced a marked decrease in CA release evoked by ACh from the intact cells (Fig. 1). The inhibitory effect of wortmannin on ACh-evoked release was dose dependent, and a significant inhibition was observed at concentrations above $0.3 \mu \mathrm{M}$. The apparent $\mathrm{IC}_{50}$ value for the inhibition was approximately $2 \mu \mathrm{M}$ that was consistent with $\mathrm{IC}_{50}$ for the inhibition of high- $\mathrm{K}^{+}$evoked and $\mathrm{Ca}^{2+}$-induced release (Ohara-Imaizumi et al., 1992b). Wortmannin at $10 \mu \mathrm{M}$ suppressed $\mathrm{ACh}$-evoked release almost completely as was observed for high- $\mathrm{K}^{+}$-evoked and $\mathrm{Ca}^{2+}$-induced release in our previous report (Ohara-Imaizumi et al., 1992b). Wortmannin did not affect either the basal release or the noradrenaline:adrenaline ratio in the released CA (data not shown). The release in the absence of $\mathrm{Ca}^{2+}$ in the digitoninpermeabilized cells was not affected by wortmannin $(4.4 \pm 0.2 \%$ and $4.1 \pm 0.2 \%$ in $10 \mu \mathrm{M}$ wortmannin-untreated and -treated cells, respectively). Wortmannin did not affect the cellular content of CA at all (data not shown). These results together with our previous findings suggest that the inhibitory action of wortmannin on the evoked CA release from intact cells and on $\mathrm{Ca}^{2+}$ induced release from the permeabilized cells is mediated by the same mechanism.

\section{Time dependency of the inhibitory action of wortmannin}

Since the inhibition of purified MLCK by wortmannin in vitro is dependent on the preincubation time that is required for the interaction of the drug with the enzyme (Nakanishi et al., 1992), we examined the effect of preincubation time on susceptibility of $\mathrm{Ca}^{2+}$-induced release from the permeabilized cells. When the cells were preincubated in the presence of $10 \mu \mathrm{M}$ wortmannin for a different time prior to the permeabilization, clear inhibition 


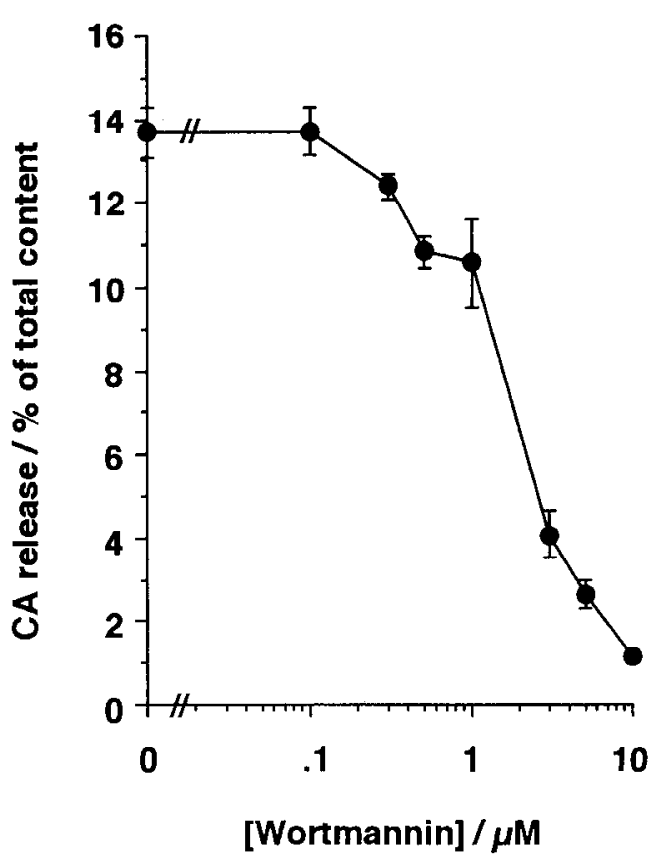

Figure 1. Dose-response curve for wortmannin inhibition of AChevoked from intact chromaffin cells. CA release from the intact cells was measured by stimulating the cells with $10^{-4} \mathrm{MACh}$ for $3 \mathrm{~min}$ following the preincubation for $30 \mathrm{~min}$ at $30^{\circ} \mathrm{C}$ in the presence or absence of increasing concentrations of wortmannin. The amounts of released $\mathrm{CA}$ are expressed as the percentage of total cellular content. Spontaneously released CA was measured for each group, and the mean value for each group was subtracted from each evoked release. Data are the mean \pm SEM of six determinations from individual wells.

of $\mathrm{Ca}^{2+}$-induced release was observed only after the preincubation for more than $15 \mathrm{~min}$, and preincubation for $30 \mathrm{~min}$ was required for nearly maximal inhibition (Fig. 2). This time dependency was similar to that observed for the interaction of wortmannin with MLCK in vitro (Nakanishi et al., 1992).

\section{Wortmannin does not inhibit $\mathrm{Ca}^{2+}$ influx}

In human platelet, our group found an effective blockade by wortmannin of a new type of $\mathrm{Ca}^{2+}$ channel that acted in the delayed phase of the response to thrombin stimulation (Hashimoto et al., 1992) Thus, it was necessary to check the effect of wortmannin on $\mathrm{Ca}^{2+}$ entry in the present study.

Stimulation of fura-2-loaded intact cells with carbamylcholine ( $\left.\mathrm{CCh} ; 2 \times 10^{-4} \mathrm{M}\right)$ by adding $100 \mu \mathrm{l}$ of $\mathrm{CCh}$ into superfusing chamber produced a transient increase of $\left[\mathrm{Ca}^{2+}\right]_{i}$ to $482 \pm 43$ nм $(n=6)$. The same concentration of $\mathrm{CCh}$ produced $\left[\mathrm{Ca}^{2+}\right]$ increase to $539 \pm 71 \mathrm{nM}(n=6)$ in wortmannin-treated cells. These concentrations of $\left[\mathrm{Ca}^{2+}\right]$ are comparable to those required for the diphosphorylation of MLC by MLCK in vitro (Itoh et al., 1992). Representative fura-2 signals are shown in Figure 3. These results suggest that wortmannin acted on the downstream $\left[\mathrm{Ca}^{2+}\right]_{i}$ increase or on the prerequisite process for $\mathrm{Ca}^{2+}$-triggering events in CA release in intact cells.

\section{Effects of SM-1 and other peptide inhibitors}

To clarify that the inhibitory action of wortmannin is attributable to its inhibition of MLCK, we examined the effects of various synthetic peptides that are known to inhibit MLCK: SM-1, K-MLC 1 1-23, MKIP, and its inactive derivatives MKIPAc. The effects of pseudosubstrate inhibitory peptides for PKC

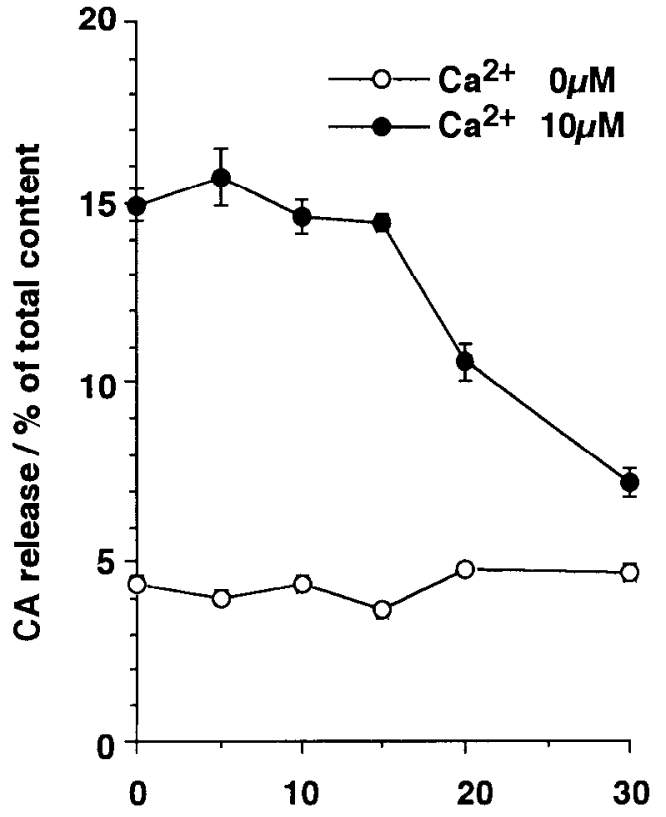

Incubation Time / min

Figure 2. Requirement of preincubation time for wortmannin inhibition of $\mathrm{Ca}^{2+}$-evoked CA release from the permeabilized cells. The cells were preincubated with $10 \mu \mathrm{M}$ wortmannin for the indicated times at $30^{\circ} \mathrm{C}$ prior to permeabilization. Permeabilization was done with 10 $\mu \mathrm{M}$ digitonin for $10 \mathrm{~min}$ in this particular experiment. The permeabilized cells were stimulated with $10 \mu \mathrm{M} \mathrm{Ca}^{2+}$ for 10 min to measure CA release. The amounts of released CA are expressed as the percentage of total cellular content. Data are the mean \pm SEM of eight determinations from individual wells. Note that wortmannin did not affect the basal release in the absence of $\mathrm{Ca}^{2+}$.

were also examined. As was shown in Figure 4, SM-1 inhibited $\mathrm{Ca}^{2+}$-induced release from the permeabilized cells by approximately $25 \%$ at $100 \mu \mathrm{M}, 50 \%$ at $370 \mu \mathrm{M}$, and $90 \%$ at $500 \mu \mathrm{M}$. K-MLC 11-23 caused approximately 20\% inhibition at $500 \mu \mathrm{M}$. MKIP was much weaker than SM-1 in inhibiting $\mathrm{Ca}^{2+}$-induced release. The inhibition by $500 \mu \mathrm{M}$ MKIP was about $15 \%$, although it was statistically insignificant, and such an inhibition was not observed with the inactive analog MKIPAc. In contrast, [Ser25]PKC(19-31) at $100 \mu \mathrm{M}$ did not affect the $\mathrm{Ca}^{2+}$-induced release from the permeabilized cells at all in good agreement with a previous report (Terbush and Holz, 1990). None of these peptides significantly affected CA release in the absence of $\mathrm{Ca}^{2+}$. It has been shown that MKIP is much less potent than SM-1 in inhibiting $\mathrm{Ca}^{2+}$ - and ATP-induced retraction of permeabilized endothelial cells (Wysolmerski and Lagunoff, 1991). The weak inhibitory action of MKIP seems to be due to the fact that this peptide is less potent in inhibiting MLCK in the permeabilized chromaffin cells as well.

These results, especially effective inhibition by SM-1 of $\mathrm{Ca}^{2+}$ induced release from the permeabilized cells, strongly suggest that the inhibitory action of wortmannin resulted from the inhibition of MLCK activation.

\section{Effects of wortmannin on time course of $\mathrm{Ca}^{2+}$-induced release}

In the time course of $\mathrm{Ca}^{2+}$-induced release from permeabilized chromaffin cells, it has been shown that the initial rate of release during first 1-2 min is not altered by the absence and presence of MgATP while MgATP is required for the release to continue 

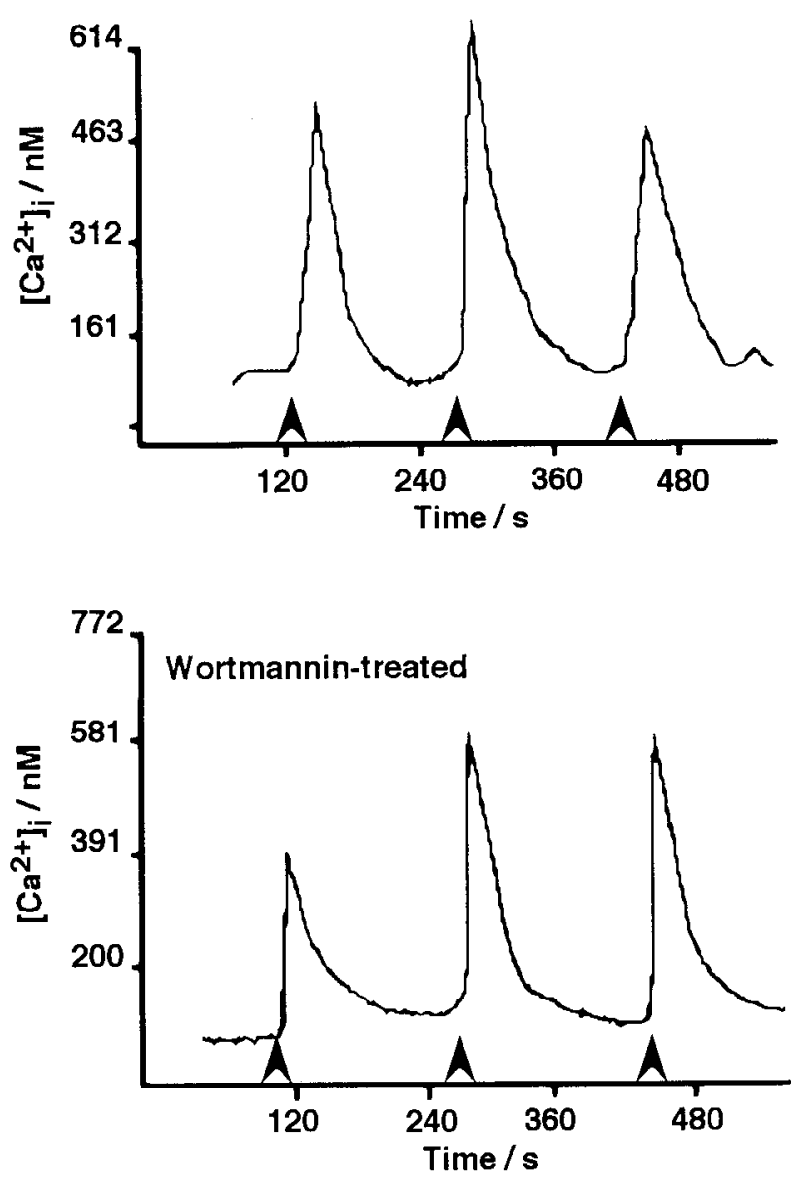

Figure 3. Effect of wortmannin on CCh-evoked increase of intracellular $\mathrm{Ca}^{2+}\left(\left[\mathrm{Ca}^{2+} l_{i}\right) . \mathrm{Ca}^{2+}\right.$ signals of a single cell were detected with a video-imaging system using fura-2 in control cells (top) and wortmannin-treated cells (bottom). The cells were preincubated with or without $10 \mu \mathrm{M}$ wortmannin for $30 \mathrm{~min}$ after loading of fura-2. Repetitive stimulation with $2 \times 10^{-4} \mathrm{M} \mathrm{CCh}$ was given in the superfusing chamber at the points indicated by arrows. Responses in $A$ and $B$ are the representative fura-2 signals. Mean values of the increased $\left[\mathrm{Ca}^{2+}\right]_{i}$ in control and wortmannin-treated cells were $482 \pm 43 \mathrm{nM}(n=6)$ and $539 \pm 71$ nм $(n=6)$, respectively.

thereafter (Holz et al., 1989). Therefore, we studied the effects of three different concentrations $(1,3$, and $10 \mu \mathrm{M})$ of wortmannin on the time course of CA release evoked by $10 \mu \mathrm{M} \mathrm{Ca}{ }^{2+}$ from the permeabilized cells. As shown in Figure 5, the time course of $\mathrm{Ca}^{2+}$-induced release in control cells apparently consisted of kinetically distinct three components: (1) the initial phase for the first $1 \mathrm{~min}$, (2) the second phase from 1 to $5 \mathrm{~min}$, (3) the third phase after $5 \mathrm{~min}$. Wortmannin reduced the release in the initial phase to about one-third of control, without any dose dependency in both the extent and secretion rate. In contrast, effects of wortmannin on the later phase were much prominent. In the cells treated with $1 \mu \mathrm{M}$ wortmannin, the release in the second and third phase persisted up to 10 min though the secretion rate was reduced. Wormannin at $3 \mu \mathrm{M}$ caused cessation of the release at 2 min without further decreasc in the ratc of this shortened second phase. Wortmannin at $10 \mu \mathrm{M}$ almost completely abolished both the second and third phase; thus, the release nearly ceased at the end of the initial phase. Consequently, the duration and final extent of the release were decreased by wortmannin with clear dose dependency that is comparable to that we reported previously (Ohara-Imaizumi et al.,

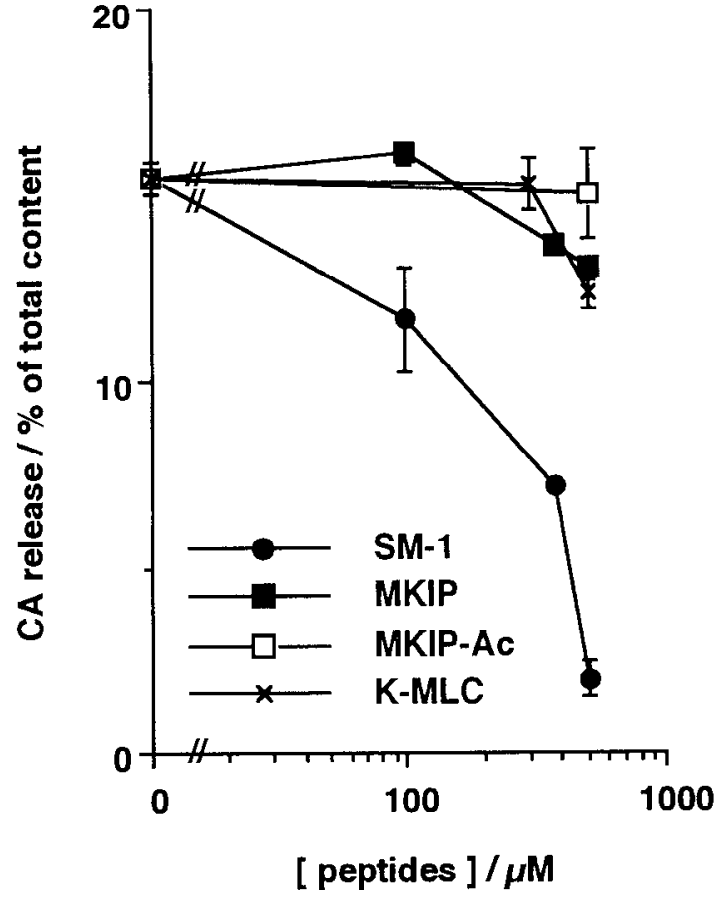

Figure 4. Effects of SM-1, K-MLC 11-23, MKIP, and MKIP-Ac on $\mathrm{Ca}^{2+}$-evoked CA release from the permeabilized cells. The cells were permeabilized with $20 \mu \mathrm{M}$ digitonin for $4 \mathrm{~min}$, and then stimulated with $10 \mu \mathrm{M} \mathrm{Ca}{ }^{2+}$ for additional $6 \mathrm{~min}$ at $30^{\circ} \mathrm{C}$. Peptide inhibitors were present during whole procedure at the indicated concentration. The amounts of released CA are expressed as the percentage of total cellular content. The amounts of released CA are expressed as the percentage of total cellular content. Amount of CA released in the absence of $\mathrm{Ca}^{2+}$ was measured for each group, and the mean value for each group was subtracted from each evoked release. Data are the mean \pm SEM of at least six determinations from individual wells. None of the peptides affected CA release in the absence of $\mathrm{Ca}^{2+}$.

1992). These results clearly suggest a requirement of MLCK activation for the continuous release that is sustained by MgATP.

Effects of wortmannin and SM-1 on ATP-dependent and ATP-independent release

To obtain further evidence for requirement of MLCK for ATPdependent release, we examined the effects of wortmannin and SM-1 on ATP-independent and ATP-dependent release from the permeabilized cells. When the cells were pretreated with 10 $\mu \mathrm{M}$ wortmannin, both ATP-independent release and ATP-dependent release were decreased approximately by $78 \%$ and by $90 \%$, respectively (Fig. 6). In contrast to wortmannin, treatment of the cells with $370 \mu \mathrm{M}$ SM-1 for 4 min prior to $\mathrm{Ca}^{2+}$ challenge caused 55\% inhibition of ATP-dependent release without any inhibition of ATP-independent release. Another inhibiting peptide, MKIP, also decreased ATP-dependent release but slightly (Fig. 7). The inhibition by SM-1 and MKIP at this concentration were close to that observed in Figure 4.

The effects of wortmannin and of SM-1 on ATP-independent release were different. One possibility seems to be that a decrement in the population of the primed granules might be caused during the longer preincubation time $(30 \mathrm{~min})$ with wortmannin but not within 4 min of preincubation with SM-1, since ATPdependent priming has been shown to be readily reversible (Holz et al., 1989; Hay and Martin, 1992). However, due to the experimental limitation with digitonin-permeabilized cells, we 


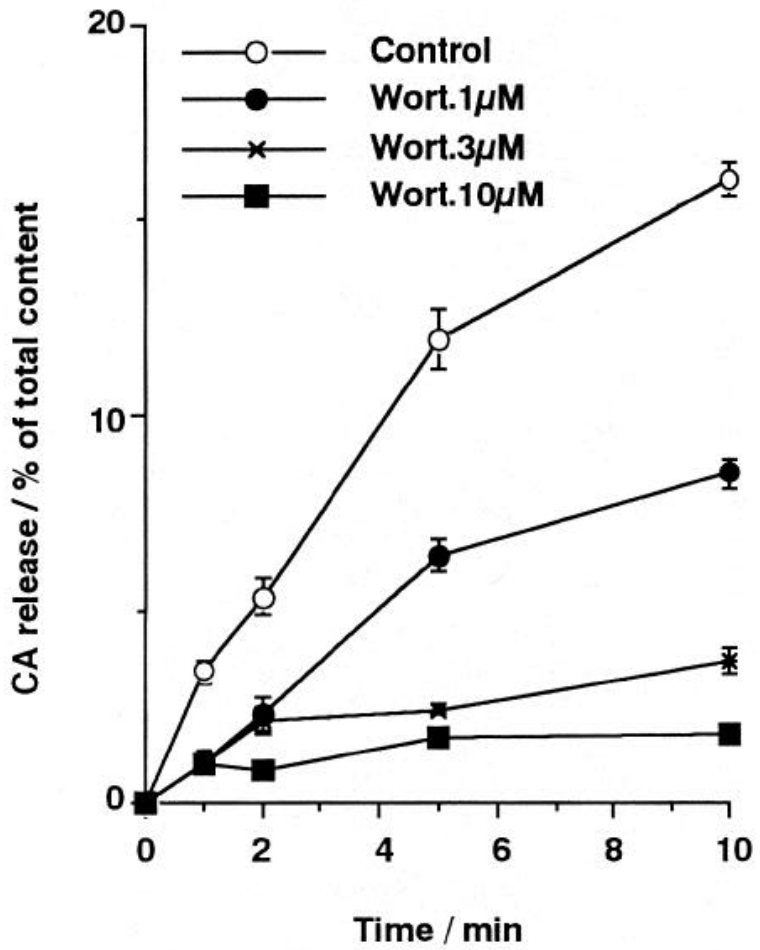

Figure 5. Effects of wortmannin on the time course of $\mathrm{Ca}^{2+}$-evoked CA release from the permeabilized cells. The cells were preincubated with or without different concentration of wortmannin for $30 \mathrm{~min}$ prior to permeabilization. The permeabilized cells were stimulated with 10 $\mu \mathrm{M} \mathrm{Ca}^{2+}$ in the presence of MgATP for the indicated times. The amounts of released CA are expressed as the percentage of total cellular content. Each value was calculated as was described in Figure 4. Data are the mean \pm SEM of at least six determinations from individual wells.

could not examine the effect of longer treatment with SM-1. The secretory activity is known to run down rapidly after digitonin permeabilization. The response to $100 \mu \mathrm{M} \mathrm{Ca}^{2+}$ at $5 \mathrm{~min}$ after $4 \mathrm{~min}$ of digitonin permeabilization decreased to $17 \%$ of the response without an interval, and the response was almost lost after $15 \mathrm{~min}$ interval (data not shown). The inhibition of ATP-independent release by wortmannin should underlie its $70 \%$ inhibition of the initial release in the time course (Fig. 5) that was not dose dependent. This may imply alternatively that the inhibition of ATP-independent release by wortmannin is due to a mechanism other than MLCK inhibition. Whatever the mechanism of the inhibition of ATP-independent release by wortmannin that remained uncertain, these results together with the results in time course (Fig. 5) indicate a requirement of MLCK for the continuous release sustained by MgATP.

\section{Wortmannin, SM-1, and K-MLC 11-23 inhibit priming action of ATP}

Since ATP-dependent release from the permeabilized cells has been suggested to be attributable to the action of ATP to prime the secretory machinery (Bittner and Holz, 1992), we examined the effect of wortmannin and MLCK-inhibiting peptides on priming action of ATP. As shown in Figure 8, priming with ATP for 4 min remarkably increased both the initial rate and final extent of ATP-independent release. Pretreatment of the cells with wortmannin caused a great decrease in the priming effects of ATP, in addition to a decrease in ATP-independent release in the unprimed cells (Fig. 8). SM-1 at $100 \mu \mathrm{M}$ caused

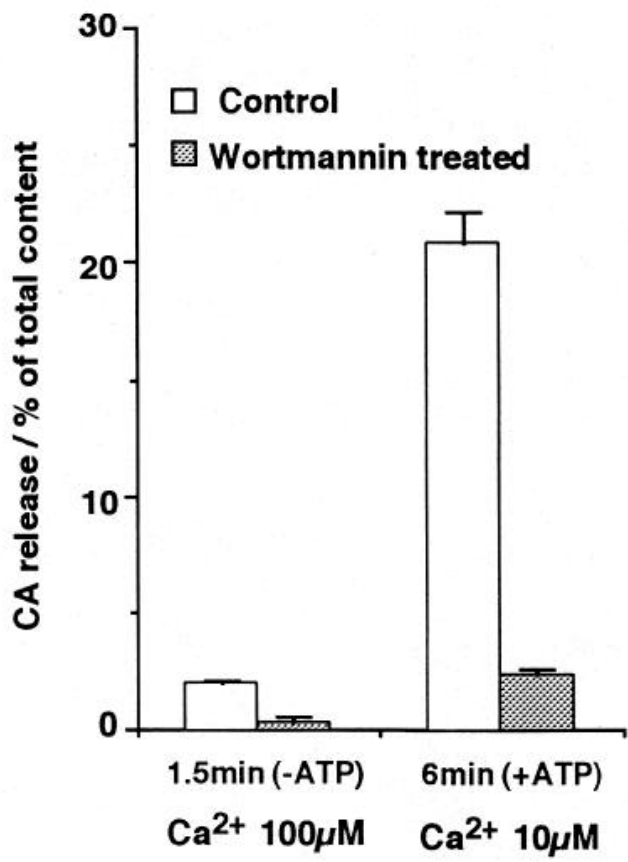

Figure 6. Effects of wortmannin on ATP-independent and ATP-dependent $C A$ release from the permeabilized cells. The cells were preincubated at $30^{\circ} \mathrm{C}$ with or without $10 \mu \mathrm{M}$ wortmannin for $30 \mathrm{~min}$ prior to permeabilization in the absence of MgATP. Then, ATP-independent $(-A T P)$ and ATP-dependent $(+A T P)$ release was measured by stimulating with $\mathrm{Ca}^{2+}$ at the indicated concentration. The amounts of released $\mathrm{CA}$ are expressed as the percentage of total cellular content. Each value was calculated as was described in Figure 4. Data are the mean \pm SEM of eight determinations from individual wells.

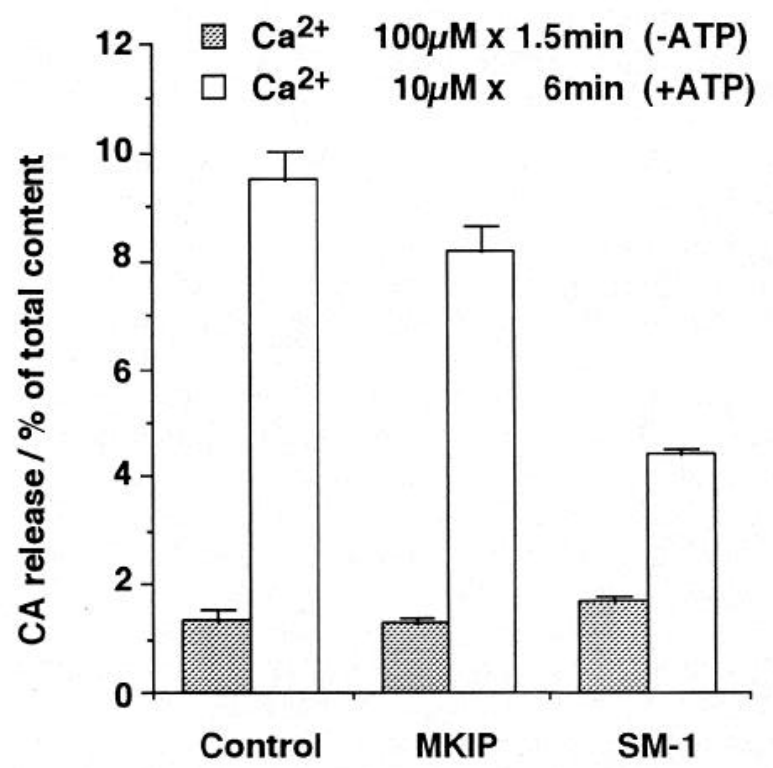

Figure 7. Effects of SM-1 and MKIP on ATP-independent and ATPdependent CA release from the permeabilized cells. SM-1 or MKIP was added at $370 \mu \mathrm{M}$ during $4 \mathrm{~min}$ of permeabilization in the absence of MgATP. ATP-independent $(-A T P)$ and ATP-dependent $(+A T P)$ release were measured by stimulating with $\mathrm{Ca}^{2+}$ at the indicated concentration. The amount of released CA is expressed as the percentage of total cellular content. Each value was calculated as was described in Figure 4. Data are the mean \pm SEM of eight determinations from individual wells. 


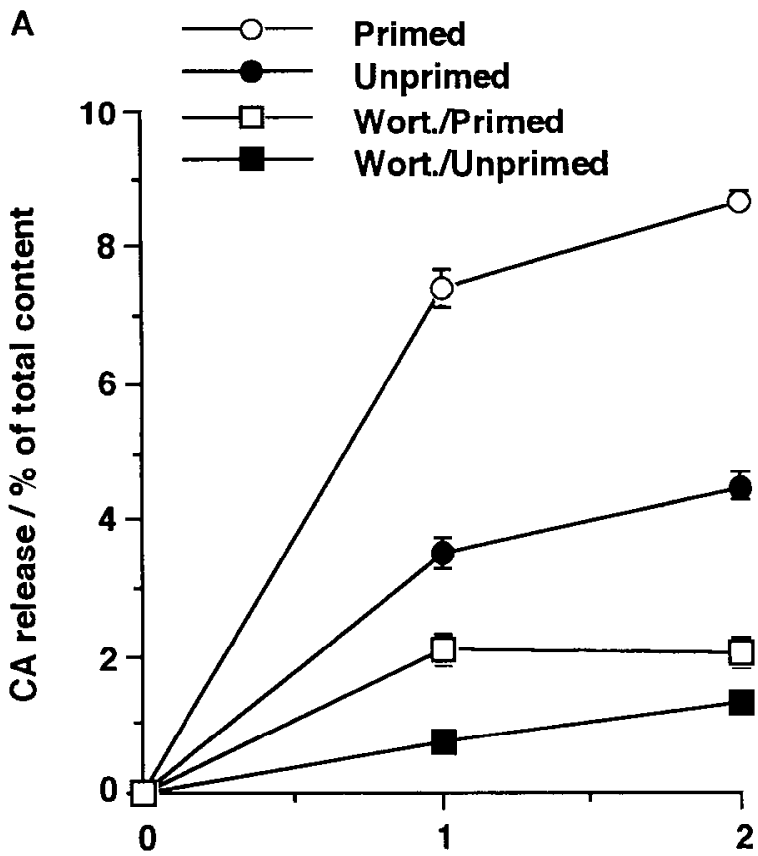

Time / $\min$
B

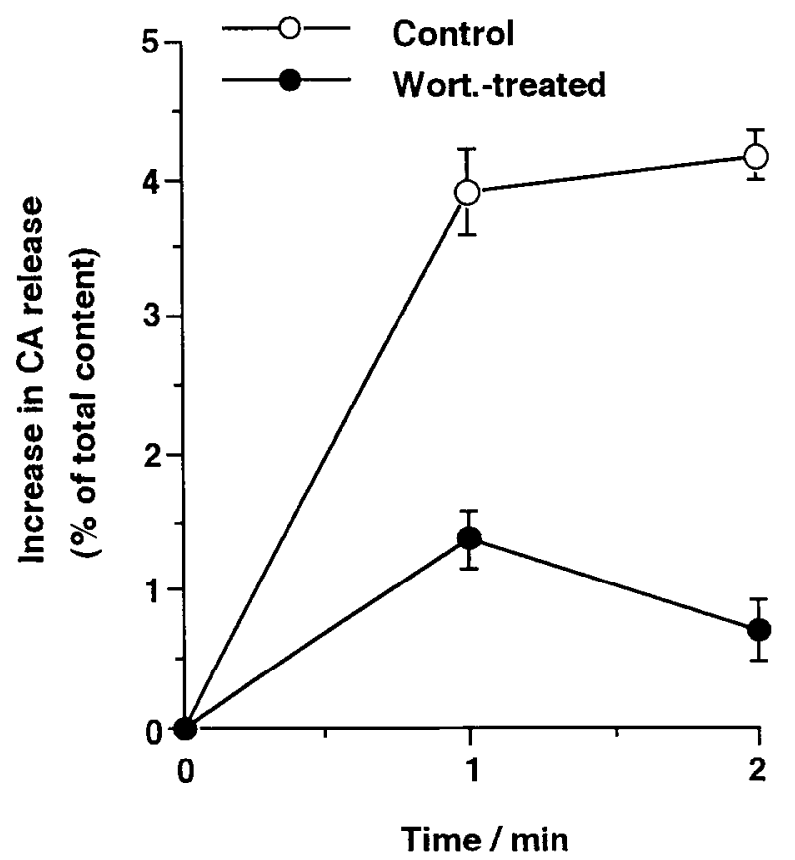

Figure 8. Effect of wortmannin (Wort.) on ATP-dependent priming of CA release in the permeabilized cells. The cells were preincubated with or without $10 \mu \mathrm{M}$ wortmannin for $30 \mathrm{~min}$ prior to permeabilization. Priming incubation with $5 \mathrm{~mm} \mathrm{MgATP}$ was done simultaneously with 4 min of permeabilization. Stimulation with $100 \mu \mathrm{M} \mathrm{Ca}{ }^{2+}$ was done for the indicated times in the absence of ATP. Amount of CA released in the absence of $\mathrm{Ca}^{2+}$ was subtracted as described in Figure 4. The amount of released CA is expressed as the percentage of total cellular content. Data are the mean \pm SEM of eight determinations from individual wells.

$36 \%$ inhibition of the priming effect of ATP, and K-MLC 1123 at $500 \mu \mathrm{M}$ caused $30 \%$ inhibition (Fig. 9). The inhibition by SM-1 at this lower concentration was more pronounced than that observed in Figure 4. These results suggest that activation of MLCK is an essential step for the priming of secretion by MgATP.

\section{Immunoblotting and immunofluorescent localization of myosin}

The myosin light chain kinases are known to possess an absolute specificity for myosin light chains (for review, see Kennelly and Krebs, 1991). Therefore, we studied the cellular distribution of antigen site for myosin antibodies in order to understand the site of MLCK implication. The anti-myosin II IgG used in this experiments specifically recognized a single band in immunoblotting of the microsome-rich fraction. The position slightly lower than that of chicken gizzard myosin heavy chain $(200$ $\mathrm{kDa}$ ) was very reasonable as nonmuscle myosin II heavy chain (Fig. 10A). Strong immunofluorescence was observed mainly at the subplasmalemmal region (Fig. $10 B$ ) as both intense rings and patched distribution. The weak immunofluorescence observed in the cytoplasmic area could be interpreted as either the subplasmalemmal distribution of myosin beneath the area or the cytoplasmic distribution as has been reported (Gutierrez et al., 1989). These immunoblotting and immunofluorescent distributions of myosin may suggest that myosin II is the most probable substrate, situated at the site of secretion, for MLCK involved in ATP-dependent priming mechanisms. Hence, phosphorylation of myosin II in the subplasmalemmal region by MLCK activation may be a part or prerequisite of the priming process.

\section{Discussion}

Is MLCK involved in the mechanism of exocytosis?

Our results suggest that MLCK is involved in the mechanisms of $\mathrm{Ca}^{2+}$-induced exocytosis in chromaffin cells as follows. Wortmannin inhibited $\mathrm{ACh}$-evoked release from the intact cells with $\mathrm{IC}_{50}$ of approximately $2 \mu \mathrm{M}$ (Fig. 1), which is consistent with $\mathrm{IC}_{50}$ for $\mathrm{Ca}^{2+}$-induced release in permeabilized cells (OharaImaizumi et al., 1992b). The preincubation time required for clear inhibition by wortmannin (Fig. 2) was very similar to that required for the interaction of this drug with MLCK in vitro (Nakanishi et al., 1992). Wortmannin inhibits MLCK activity acting irreversibly at or near the catalytic site of the enzyme, whereas it had no effect on cAMP-dependent protein kinase, cGMP-dependent protein kinase, $\mathrm{Ca}^{2+} /$ calmodulin-dependent protein kinase II, and little effect on PKC (Nakanishi et al., 1992). Although we found very recently that wortmannin also inhibits phosphatidylinositol 3-kinase (Yano et al., 1993), its $\mathrm{IC}_{50}(2-3 \mathrm{nM})$ is extremely lower than that for the inhibition of MLCK (Nakanishi et al., 1992) and of CA release observed here. Hence, the inhibition of CA release by wortmannin observed here seems to be attributable to its inhibitory action on MLCK.

Among MLCK-inhibiting peptides, SM-1 at $500 \mu \mathrm{M}$ produced almost complete inhibition of $\mathrm{Ca}^{2+}$-induced release from the permeabilized cells. Another MLCK-inhibiting peptide, K-MLC 11-23, caused a significant inhibition, while MKIP was much weaker (Fig. 4). SM-1 is known to be extremely potent (Foster et al., 1990) and highly specific inhibitor for MLCK (Kargacin et al., 1990). The primary structure of nonmuscle MLCK and that of smooth muscle MLCK are identical except for N-ter- 


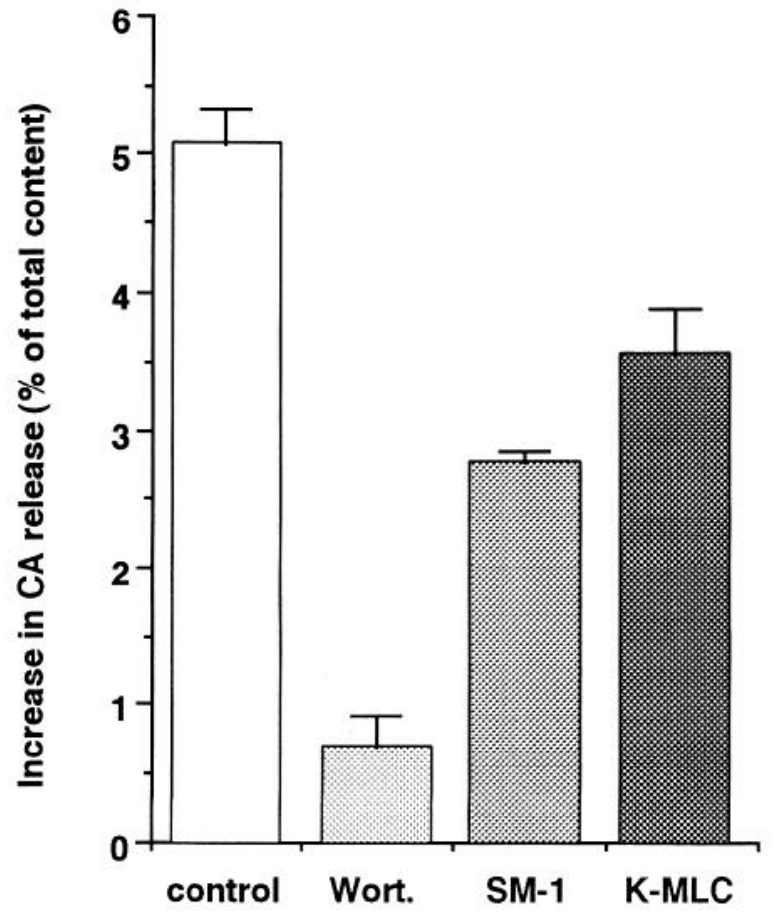

Figure 9. Effects of SM-1 and K-MLC 11-23 on ATP-dependent priming of CA release in the permeabilized cells. Priming incubation with $5 \mathrm{~mm} \mathrm{MgATP}$ was done simultaneously with $4 \mathrm{~min}$ of permeabilization in the presence or absence of $100 \mu \mathrm{M} \mathrm{SM}-1$ or of $500 \mu \mathrm{M} \mathrm{K}-\mathrm{MLC} 11-$ $23(K-M L C)$. MgATP-independent release for $1.5 \mathrm{~min}$ was then measured in the absence of the inhibiting peptide. Value is the extent of increase by priming. Mean value of the release in unprimed cells was subtracted from individual value of the release in primed cells. The peptides affected neither the basal release nor the release from the unprimed cells. Data are the mean \pm SEM of eight determinations from individual wells. Inhibition by wortmannin (Wort.) detected at $2 \mathrm{~min}$ in Figure 8 was also shown.

minal region (Shoemaker et al., 1990). Therefore, the inhibition of CA release by SM-1 in the present results can be interpreted as a result from specific inhibition of MLCK. Significant inhibition by K-MLC 11-23 supports this interpretation. The $\mathrm{IC}_{50}$ of SM-1 for this inhibition seems considerably high. However, SM-1 was recently shown to inhibit voltage-dependent potassium currents in sympathetic neurons, and a concentration as high as $100 \mu \mathrm{M}$ was required for clear inhibition even with an intracellular injection (Akasu et al., 1993). Exces ' presence of endogenous substrate and possible leakage of protein phosphatase from cytosol in our experimental condition might explain the requirement of this high concentration. MKIP was much less potent than SM-1 as was reported for $\mathrm{Ca}^{2+}$ - and ATPinduced retraction of permeabilized endothelial cells (Wysolmerski and Lagunoff, 1991).

Anti-calmodulin antibody has been shown to inhibit high$\mathrm{K}^{+}$-evoked and $\mathrm{ACh}$-evoked $\mathrm{CA}$ release when introduced into chromaffin cells (Kenigsberg and Trifaro, 1985). This seems to be consistent with the present findings, since MLCK is a $\mathrm{Ca}^{2+}$ / calmodulin-activated enzyme.

\section{How is MLCK involved?}

$\mathrm{Ca}^{2+}$-induced release of CA from the permeabilized chromaffin cells or from the semiintact $\mathrm{PC} 12$ cells has been resolved into at least two distinct stages: MgATP-dependent priming of secretion, and $\mathrm{Ca}^{2+}$-triggered ATP-independent release from the primed pool (Bittner and Holz, 1992; Hay and Martin, 1992). In $\mathrm{Ca}^{2+}$-induced release from digitonin-permeabilized chromaffin cells, the initial release for 1-2 min reflects ATP-independent release from the primed pool, and the release thereafter is sustained by ATP-dependent priming (Holz et al., 1989; Bittner and Holz, 1992). The former of these two components can be distinguished as the release evoked by $100 \mu \mathrm{M} \mathrm{Ca}{ }^{2+}$ in the absence of ATP that terminates by 1-2 min, thus termed ATPindependent release. The latter one is distinguished as the release evoked by $10 \mu \mathrm{M} \mathrm{Ca}^{2+}$ in the presence of MgATP that continues for 10-12 min, thus termed ATP-dependent release.

In addition, the priming effect of ATP can be observed as such that preincubation of permeabilized cells with MgATP enhances $\mathrm{Ca}^{2+}$-dependent release during a subsequent incubation in the absence of MgATP either in chromaffin cells or in PC12 cells (Holz et al., 1989; Hay and Martin, 1992). Similar multiple processes of $\mathrm{Ca}^{2+}$-dependent release in chromaffin cells were suggested very recently from kinetic analysis of the membrane capacitance and intracellular $\mathrm{Ca}^{2+}$ concentration measured simultaneously (Neher and Zucker, 1993).

The time course of $\mathrm{Ca}^{2+}$-induced release from the permeabilized cells in this study consisted of kinetically distinct three components. Wortmannin differently affected these three stages, and the effects of wortmannin were more pronounced on the
A

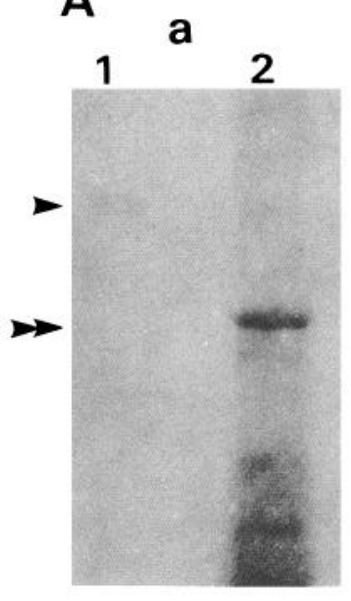

b

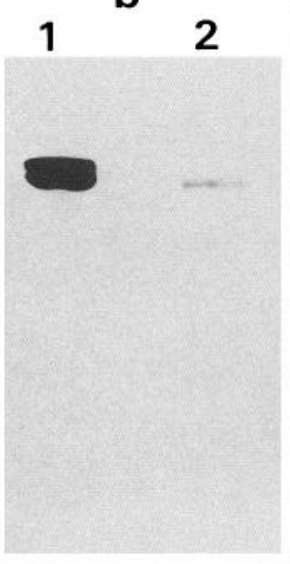

B
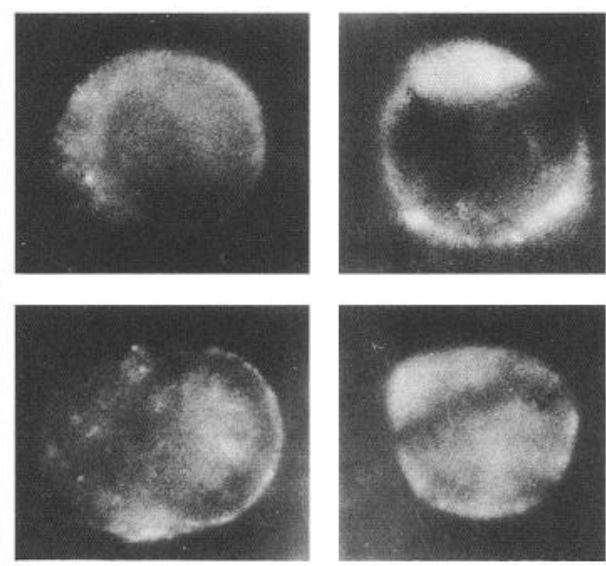

Figure 10. A, Immunoblotting results by anti-myosin II IgG: $a$, protein staining by Ponceau staining; $b$, immunostaining; $I$, chicken gizzard myosin; 2 , membrane rich fraction from chromaffin cells. Arrowhead indicates the position of $200 \mathrm{kDa}$ molecular weight of myosin II heavy chain. Double arrowhead indicates the position of $100 \mathrm{kDa}$. The band at $100 \mathrm{kDa}$ in protein staining shows perhaps the Ca-ATPase in membrane fraction. $B$, Distribution of myosin in chromaffin cells detected by Immunofluorescent method. 
release during the second and third phases than on the initial release. Wortmannin reduced dose dependently both the rate and duration of the release in the second and third phases (Fig. 5). Consistently, ATP-dependent release was inhibited by SM1, while ATP-independent release was not affected at all (Fig. 7). The priming by MgATP that underlies ATP-dependent release was inhibited remarkably by wortmannin, and significantly by either SM-1 or K-MLC 11-23 (Figs. 8, 9). All of these results clearly suggest that MLCK has an essential role in ATP-dependent priming pathway.

A question arises, then, whether phosphorylation of $\mathrm{MLC}_{20}$ mediates the putative role of MLCK or not in the regulated exocytosis. The catalytic and calmodulin regulatory segments of nonmuscle MLCK are virtually identical to that of smooth muscle MLCK (Shoemaker et al., 1990). The sequences around the phosphorylation sites of smooth muscle and nonmuscle myosin II of higher eukaryotes are highly conserved (for review, see Tan et al., 1992). These findings imply that also nonmuscle MLCK may possess an absolute specificity for MLC ${ }_{20}$. Phosphorylation of $\mathrm{MLC}_{20}$ by activated MLCK regulates the actinmyosin interaction in contraction of smooth muscle (for review, see Adelstein and Eisenberg, 1980). The phosphorylated adrenal medullary myosin has been shown to enhance the actin-activated $\mathrm{Mg}^{2+}$-ATPase activity (Kanda et al., 1985). However, an implication of actin-myosin interaction in the putative role of MLCK for ATP-dependent priming remains uncertain for two reasons. First, the role of actin as a barrier to the movement of secretory vesicles to exocytotic sites has been suggested (Aunis and Bader, 1988; Vitale et al., 1991; reviewed by Trifaro et al., 1992). If actin-myosin interaction is involved in ATP-dependent priming, therefore, the actin should be distinct from filamentous actin that acts as a barrier. One may speculate the interaction of myosin with oligomeric actin molecules. In this regard, electron microscopic studies by quick freezing and deep etching have demonstrated that exocytosis occurred more frequently in the areas with few actin network (Nakata and Hirokawa, 1992). Second, MLCK was suggested very recently to modulate voltage-dependent potassium current (Akasu et al., 1993). This implies that phosphorylated $\mathrm{MLC}_{20}$ might interact with unknown molecules in the vicinity of the channel molecule or the channel it self. Such molecules might be membranebound proteins, and priming of secretion might be affected by an interaction of myosin with such molecules.

The present results do not exclude partial responsibility of phosphatidylinositol (PI) kinase or PI transfer protein for ATPdependent priming of exocytosis (Holz et al., 1989; Hay and Martin, 1993). However, an essential role of PI 3-kinase at least is unlikely considering $\mathrm{IC}_{50}$ of wortmannin for inhibition of the cnzyme (Yano ct al., 1993). IC $_{50}$ of wortmannin in the present results $(1 \mu \mathrm{M})$ is more consistent with the inhibition of MLCK. It is likely that priming process is regulated through multiple reactions. From this point of view, MLCK or phosphorylation of $\mathrm{MLC}_{20}$ may be one of the essential components for priming.

The putative role of MLCK in the mechanism of exocytosis suggested here might be quite common and fundamental in different neurosecretory cells, since we now know that wortmannin inhibits secretory function in the various types of cells such as rat basophilic leukemia cells, human basophils (Kitani et al., 1992), PC12 cells (Inoue and Kumakura, 1992), and cultured rat sympathetic ganglion (Mochida et al., 1992; Muramoto et al., 1993). In cultured rat sympathetic ganglion, particularly, inhibition of neurotransmitter release at presynaptic terminal by intracellular injection of SM-1 and anti-myosin antibodies was clearly demonstrated by detecting EPSP in response to presynaptic stimulation. In that study, the initial burst of the transmitter release seems to be resistant to wortmannin while the sustained release is effectively blocked by the inhibitor. Thus, MLCK seems to be essential for priming of exocytosis also in sympathetic nerve terminals (S. Mochida, H. Kobayashi, Y. Matsuda, Y. Yuda, K. Muramoto, and Y. Nonomura, unpublished observation).

In conclusion, our results strongly suggest an essential role of MLCK for priming of exocytosis. Most probably phosphorylation of $\mathrm{MLC}_{20}$ by MLCK activation plays an essential role in ATP-dependent priming of exocytotic machinery. It has to be determined whether phosphorylation of $\mathrm{MLC}_{20}$ is essential as the intrinsic mechanism of priming or as the microenvironment to maintain priming. Reevaluation of the role of $\mathrm{MLCK}$ in $\mathrm{Ca}^{2+}$ dependent exocytosis is desirable in terms of ATP-dependent priming mechanism.

\section{References}

Adelstein RS, Eisenberg E (1980) Regulation and kinetics of actinmyosin-ATP interaction. Annu Rev Biochem 49:921-956.

Akasu K, Ito M, Nakano T, Schneider CR, Simmons MA, Tanaka T, Tokimasa T, Yoshida M (1993) Myosin light chain kinase occurs in bullfrog sympathetic neurons and may modulate voltage-dependent potassium currents. Neuron 11:1-13.

Ali SM, Geisow MJ, Burgoyne RD (1989) A role for calpactin in calcium-dependent exocytosis in adrenal chromaffin cells. Nature 340: 313-315.

Aunis D, Bader MF (1988) The cytoskeleton as a barrier to exocytosis in secretory cells. J Exp Biol 139:253-266.

Bittner MA, Holz RW (1992) Kinctic analysis of secretion from permeabilized adrenal chromaffin cells reveals distinct components. J Biol Chem 267:16219-16225.

Bittner MA, Holz RW, Neubig RR (1986) Guanine nucleotide effects on catecholamine secretion from digitonin-permeabilized adrenal chromaffin cells. J Biol Chem 261:10182-10188.

Darchen F, Zahraoui A, Hammel F, Mouteils M-P, Tavitian A, Scherman D (1990) Association of the GTP-binding protein Rab3A with bovine adrenal chromaffin granules. Proc Natl Acad Sci USA 87: 5692-5696.

Douglas WW, Rubin RP (1964) The effects of alkaline earths and other divalent cations on adrenal medullary secretion. J Physiol (Lond) 175:231-241.

Elferink LA, Peterson MR, Scheller RH (1993) A role or synaptotagmin (p65) in regulated exocytosis. Cell 72:153-159.

Foster CJ, Johnston SA, Sunday B, Gaeta FC (1990) Potent peptide inhibitors of smooth muscle myosin light chain kinase: mapping of the pseudosubstrate and calmodulin binding domains. Arch Biochem Biophys 280:397-404.

Grynkiewicz. G, Poenie M, Tsien RY (1985) A new generation of $\mathrm{Ca}^{2+}$ indicators with greatly improved fluorescence properties. J Biol Chem 260:3440-3450.

Gutierrez LM, Hidalgo MJ, Palmero M, Ballesta JJ, Reig JA, Garcia AG, Viniegra S (1989) Phosphorylation of myosin light chain from adrenomedullary chromaffin cells in culture. Biochem J 264:589-596.

Hashimoto Y, Ogihara A, Nakanishi S, Malsuda Y, Kurokawa K, Nonomura Y (1992) Two thrombin-activated $\mathrm{Ca}^{2+}$ channels in human platelets. J Biol Chem 267:17078-17081.

Hay JC, Martin TF (1992) Resolution of regulated secretion into sequential MgATP-dependent and calcium-dependent stages mediated by distinct cytosolic proteins. J Cell Biol 119:139-151.

Hay JC, Martin TF (1993) Phosphatidylinositol transfer protein required for ATP-dependent priming of $\mathrm{Ca}^{2+}$-activated secretion. Nature 366:572-575.

Holz RW, Bittner MA, Peppers SC, Senter RA, Eberhard DA (1989) MgATP-independent and MgATP-dependent exocytosis. Evidence that MgATP primes adrenal chromaffin cells to undergo exocytosis. J Biol Chem 264:5412-5419.

Howell TW, Kramer IM, Gomperts B (1989) Protein phosphorylation 
and the dependence on $\mathrm{Ca}^{2+}$ and GTP- $\gamma-\mathrm{S}$ for exocytosis from permeabilized mast cells. Cell Signal 1:157-163.

Hunt JT, Floyd DM, Lee VG, Little DK, Moreland S (1989) Minimum requirement for inhibition of smooth-muscle myosin light-chain kinase by synthetic peptides. Biochem J 257:73-78.

Inoue K, Kumakura K (1992) Inhibition of ATP-evoked dopamine release by wortmannin, a myosin light chain kinase inhibitor. Neurosci Res [Suppl] 17:S80.

Itoh K, Hara T, Yamada F, Shibata N (1992) Diphosphorylation of platelet myosin ex vivo in the initial phase of activation by thrombin. Biochim Biophys Acta 1136:52-56.

Kanda K, Sobue K, Kakiuchi S (1985) Phosphorylation of myosin light chain and the actin-activated ATPase activity of adrenal medullary myosin. J Biochem 97:961-964.

Kargacin GJ, Ikebe M, Fay FS (1990) Peptide modulators of myosin light chain kinase affect smooth muscle cell contraction. Am J Physiol 259:C315-C326.

Kenigsberg RL, Trifaro J-M (1985) Microinjection of calmodulin antibodies into cultured chromaffin cells blocks catecholamine release in response to stimulation. Neuroscience 14:335-337.

Kennelly PJ, Krebs EG (1991) Consensus sequences as substrate specificity determinants for protein kinases and protein phosphatases. J Biol Chem 266:15555-15558.

Kitani S, Teshima R, Morita Y, Ito K, Matsuda Y, Nonomura Y (1992) Inhibition of IgE-mediated histamine release by myosin light chain kinase inhibitors. Biochem Biophys Res Commun 183:48-54.

Knight DE, Baker PF (1985) Guanine nucleotides and Ca-dependent exocytosis. FEBS Lett 189:345-349.

Kumakura K, Ohara M, Sato GP (1986) Real-time monitoring of the secretory function of cultured adrenal chromaffin cells. J Neurochem 46:1851-1858.

Lee SA, Holz RW, Hathaway DR (1987) Effects of purified myosin light chain kinase on myosin light chain phosphorylation and catecholamine secretion in digitonin-permeabilized chromaffin cells. Biosci Rep 7:323-332.

Mochida S, Nonomura Y, Kobayashi H (1992) Effect of myosin light chain kinase inhibitor, wortmannin, on neurotransmitter release at the synapse formed in culture. Neurosci Res [Suppl] 17:S91.

Morgan A, Burgoyne RD (1990) Relationship between arachidonic acid release and $\mathrm{Ca}^{2+}$-dependent exocytosis in digitonin-permeabilized bovine adrenal chromaffin cells. Biochem J 271:571-574.

Morgan A, Burgoyne RD (1992) Exo-1 and Exo-2 proteins stimulate calcium-dependent exocytosis in permeabilized adrenal chromaffin cells. Nature 355:833-835.

Muramoto K, Mochida S, Matsuda Y, Yuda Y, Kuroda Y, Nonomura $Y$ (1993) Role of myosin in transmitter release at rat sympathetic ganglion. Jpn J Pharmacol 61[Suppl 1]:70P.

Nakamura S, Nonomura Y (1984) A simple and rapid method to remove light chain phosphatase from chicken gizzard myosin. J Biochem 96:575-578.

Nakanishi A, Yoshizumi M, Hamano S, Morita K, Oka M (1989) Myosin light-chain kinase inhibitor, 1-(5-chlornaphthalene-1-sulfonyl)-1H-hexahydro-1,4-diazepine (ML-9), inhibits catecholamine secretion from adrenal chromaffin cells by inhibiting $\mathrm{Ca}^{2+}$ uptake into the cells. Biochem Pharmacol 38:2615-2619.

Nakanishi S, Kakita S, Takahashi I, Kawahara K, Tsukuda E, Sano T, Yamada K, Yoshida M, Kase H, Matsuda Y, Hashimoto Y, Nonomura Y (1992) Wortmannin, a microbial product inhibitor of myosin light chain kinase. J Biol Chem 267:2157-2163.

Nakata T, Hirokawa N (1992) Organization of cortical cytoskeleton of cultured chromaffin cells and involvement in secretion as revealed by quick-freeze, deep-etching, and double-label immunoelectron microscopy. J Neurosci 12:2186-2197.

Nanninga LB, Kempen R (1971) Roles of magnesium and calcium in the first and second contraction of glycerin-extracted muscle fibers. Biochemistry 10:2449-2456.

Neher E, Zucker RS (1993) Multiple calcium-dependent processes related to secretion in bovine chromaffin cells. Neuron 10:21-30.

Nishizaki T, Walent JH, Kowalchyk JA, Martin TJ (1992) A key role for 145-kDa cytosolic protein in the stimulation of $\mathrm{Ca}^{2+}$-dependent secretion by protein kinase C. J Biol Chem 267:23972-23981.

Ohara-Imaizumi M, Kameyama K, Kawae N, Takeda K, Muramatsu S, Kumakura K (1992a) Regulatory role of the GTP-binding protein, Go, in the mechanism of exocytosis in adrenal chromaffin cells. J Neurochem 58:2275-2284.

Ohara-Imaizumi M, Sakurai T, Nakamura S, Nakanishi S, Matsuda Y, Muramatsu S, Nonomura Y, Kumakura K (1992b) Inhibition of $\mathrm{Ca}^{2+}$-dependent catecholamine release by myosin light chain kinase inhibitor, wortmannin, in adrenal chromaffin cells. Biochem Biophys Res Commun 185:1016-1021.

Perin MS, Brose N, Jahn R, Sudhof TC (1991) Domain structure of synaptotagmin (p65). J Biol Chem 266:623-629.

Poisner AM, Trifaro J-M (1967) The role of ATP and ATPase in the release of catecholamines from the adrenal medulla. I. ATP-evoked release of catecholamine, ATP, and protein from isolated chromaffin granules. Mol Pharmacol 3:361-371.

Sarafian T, Aunis D, Bader M-F (1987) Loss of proteins from digitonin-permeabilized adrenal chromaffin cells essential for exocytosis. J Biol Chem 262:16671-16676.

Shoemaker MO, Lau W, Shattuck RL, Kwiatkowski AP, Matrisian PE, Guerra-Santos L, Wilson E, Lukas TJ, Van Eldik LJ, Watterson DM (1990) Use of DNA sequence and mutant analysis and antisense oligodeoxynucleotides to examine the molecular basis of nonmuscle myosin light chain autoinhibition, calmodulin recognition, and activity. J Cell Biol 111:1107-1125.

Tan JL, Ravid S, Spudich JA (1992) Control of nonmuscle myosins by phosphorylation. Annu Rev Biochem 61:721-759.

Terbush DR, Holz RW (1990) Activation of protein kinase C is not required for exocytosis from bovine adrenal chromaffin cells. J Biol Chem 265:21179-21184.

Trifaro J-M (1978) Contractile proteins in tissues originating in the neural crest. Neuroscience 3:1-24.

Trifaro J-M, Del Castillo R, Vitale ML (1992) Dynamic changes in chromaffin cell cytoskeleton as prelude to exocytosis. Mol Neurobiol 6:339-358.

Vitale ML, Rodriguez Del Castillo A, Tachakarov L, Trifaro JM (1991) Cortical filamentous actin disassembly and sinderin redistribution during chromaffin stimulation precede exocytosis, a phenomenon not exhibited by gelsolin. J Cell Biol 113:1057-1067.

Vitale N, Mukai H, Rouot B, Thierse D, Aunis D, Bader M-F (1993) Exocytosis in chromaffin cells. Possible involvement of the heterotrimeric GTP-binding protein $G_{0}$. J Biol Chem 268:14715-14723.

Wilson SP (1990) Regulation of chromaffin cell secretion and protein kinase $\mathrm{C}$ activity by chronic phorbol ester treatment. J Biol Chem 265:648-651.

Wysolmerski RB, Lagunoff D (1991) Regulation of permeabilized endothelial cell retraction by myosin phosphorylation. Am J Physiol 261:C32-C40.

Yano H, Nakanishi S, Kimura K, Hanai N, Saitoh Y, Fukui Y, Nonomura Y, Matsuda Y (1993) Inhibition of histamine secretion by wortmannin through the blockade of phosphatidylinositol 3-kinase in RBL-2H3 cells. J Biol Chem 268:25846-25856. 